\title{
Vitamin E in Atopic Dermatitis: From Preclinical to Clinical Studies
}

\author{
Cheryl Wei Ling Teo ${ }^{a, b}$ Shawn Han Yueh Tay ${ }^{c}$ Hong Liang Tey ${ }^{d-f}$ \\ Yee Wei Ung ${ }^{b}$ Wei Ney Yap ${ }^{a, b}$ \\ ${ }^{a}$ Research and Development Department, Davos Life Science, Singapore, Singapore; ${ }^{b}$ Research and Development \\ Department, KL-Kepong Oleomas Sdn Bhd (KLK-Oleo), Selangor, Malaysia; ' School of Biological Sciences, Nanyang

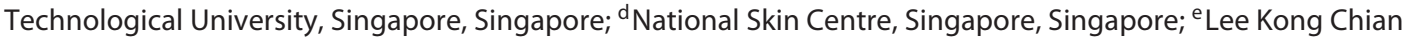 \\ School of Medicine, Nanyang Technological University, Singapore, Singapore; ${ }^{f}$ Yong Loo Lin School of Medicine, \\ National University of Singapore, Singapore, Singapore
}

\section{Keywords}

Vitamin E - Tocopherols - Tocotrienols - Atopic dermatitis . Atopic eczema

\section{Abstract}

Background: Oxidative stress and inflammation are some of the proposed mechanisms involved in the pathogenesis of atopic dermatitis (AD). Current pharmacotherapeutic approaches are effective yet they are not without adverse effects. Vitamin E has great potential as an adjunctive treatment for AD owing to its antioxidant and anti-inflammatory bioactivities. Summary: This review article summarizes the current available evidence from cellular, animal and clinical studies on the relationship between vitamin $E$ and $A D$. The future prospects of vitamin $E$ are also discussed. Vitamin $E$ in practice does not show any toxicity to humans within a range of reasonable dosage. Albeit rarely, vitamin $\mathrm{E}$ as a contact allergen should be considered. Collectively, this review envisaged vitamin $E$ as an adjunctive treatment for $A D$ patients. Future research on the distinct effects of different vitamin $\mathrm{E}$ isoforms as well as their delivery system in skin disorders is needed.

(c) 2020 S. Karger AG, Basel

\section{Introduction}

Atopic dermatitis (AD), the most common form of eczema, is a non-contagious, chronic pruritic skin disease that affects approximately $15-20 \%$ of children and 3-5\% of adults worldwide [1]. It begins early in life, erratically regresses after puberty and some cases will continue into adulthood, affecting both physical health and social life. Although the underlying aetiopathogenesis of $\mathrm{AD}$ is still poorly understood, the pathophysiology evidence suggests $\mathrm{AD}$ as a complex multifactorial disorder, manifesting an impaired epidermal barrier and dysregulated immune response [2-4]. Recently, the role of oxidative stress (OS) in $\mathrm{AD}$ has been widely studied. In high amounts, reactive oxidants cause cellular damage to epidermal keratinocytes through lipid peroxidation [5]. Evidence also suggests the contribution of OS to tissue inflammation through upregulation of genes responsible for pro-inflammatory cytokines via the nuclear factor- $\kappa B$ pathway $[6,7]$.

There is currently no long-term cure for $\mathrm{AD}$, and the present pharmacotherapeutic approach includes corticosteroids, calcineurin inhibitors and antihistamines [8]. While proven effective, the current available drugs are

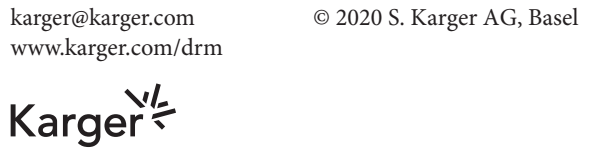

Cheryl Wei Ling Teo or Wei Ney Yap 
Fig. 1. Flow diagram of the study screening process.

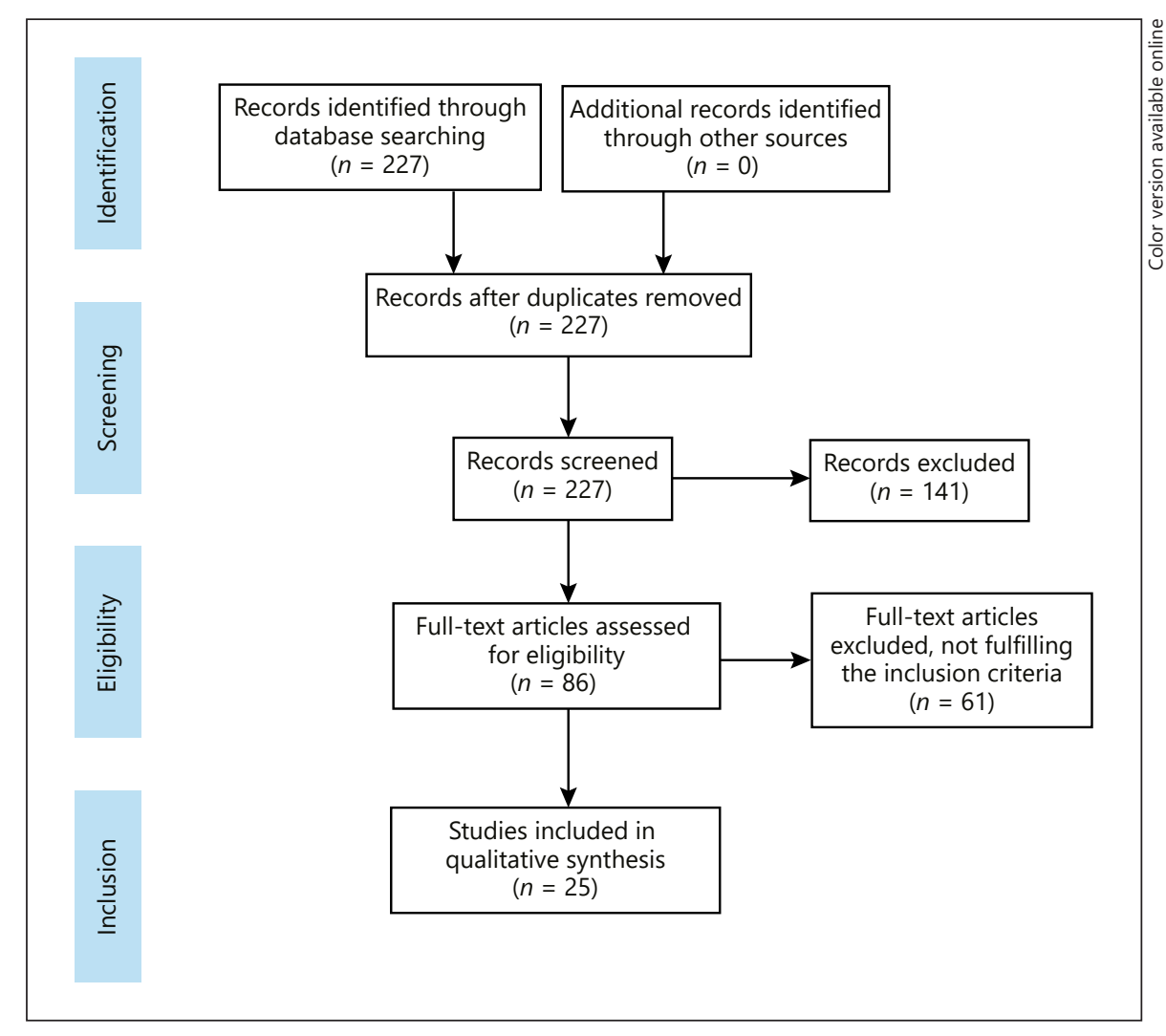

not without adverse effects. Naturally occurring phenolic antioxidants such as vitamin $\mathrm{E}$ have been shown to play a modest role in $\mathrm{AD}$ [9-12]. "Vitamin E" is a collective term for tocopherols (TP) and tocotrienols (T3), which mainly differ in their aliphatic tail. T3 has been shown to display a superior antioxidant effect as compared to TP due to its unsaturated and isoprenoid side chain [13-15]. Apart from its antioxidant activity, vitamin $\mathrm{E}$ is able to suppress inflammation and upregulate gene expression of keratinocyte differentiation markers, suggesting its potential as a therapeutic agent against $\operatorname{AD}[16,17]$.

The majority of $\mathrm{AD}$ patients are treated with oral and transdermal vitamin E. Several randomized controlled trials suggested vitamin E supplementation could improve $\mathrm{AD}$ clinical manifestations and inflammatory allergic responses $[9,11,12,18,19]$. Lately, incorporation of micronutrients in nanotechnology-based therapeutics has been shown to improve the bioavailability of poorly aqueous solubility vitamins [20]. Vitamin E nanoformulations have been found to be advantageous in enhancing the delivery efficacy and skin retention [21-23]. In this review, we aim to summarize the current available studies and evidence pertaining to the efficacy and safety for the use of vitamin $\mathrm{E}$ treatment in $\mathrm{AD}$, and hence its future prospects.

\section{Literature Search}

The literature search from January 1994 through March 2019 was conducted via the PubMed/MEDLINE database using the keywords ("Vitamin E" OR "tocopherols" OR "tocotrienols") AND ("atopic dermatitis" OR "atopic eczema" OR "eczema"). All the search results were identified by titles followed by abstracts to find articles for further full-text screening before final inclusion in the systematic review. The selection process has followed the Preferred Reporting Items for Systematic Reviews and Meta-Analyses (PRISMA) guidelines as shown in Figure 1. A total of 25 studies (5 cellular studies, 4 animal studies and 16 human studies) met our criteria.

Most studies have used the term "vitamin E" indiscriminately. To provide the reader with clarity and a better understanding of the effects of the various isoforms of vitamin E, we will specify the isoforms of vitamin $\mathrm{E}$ in our discussion below unless omitted from the original papers. In such cases, we will use the general term "vitamin E" as mentioned in the original papers.

\section{Preclinical Evidence from Cellular Studies}

To investigate the role of vitamin $\mathrm{E}$ in the regulation of OS, Masaki et al. [24] cultivated $\mathrm{HaCaT}$ cells with $\alpha$-TP for $24 \mathrm{~h}$ and measured the level of intracellular glutathione, a crucial protein involved in removing excess intra- 
Table 1. A summary showing the preclinical evidence for vitamin E in cellular studies

\begin{tabular}{llll}
\hline Researchers, year & Study design & Doses & Outcomes \\
\hline $\begin{array}{l}\text { Masaki et al. } \\
\text { [24], 2002 }\end{array}$ & HaCaT keratinocytes & $\begin{array}{l}\alpha \text {-TP } \\
50 \text { and } 100 \mu \mathrm{M}\end{array}$ & $\begin{array}{l}\text { Positive outcomes: } \\
\text {-TP promoted antioxidant defense system possibly by inhibiting GSH } \\
\text { consumption and stimulating GSH synthesis in HaCaT cells }\end{array}$ \\
\hline $\begin{array}{l}\text { Gehin et al. } \\
\text { [25], 2006 }\end{array}$ & HaCaT keratinocytes & $\begin{array}{l}\text { Trolox } \\
100 \mu \mathrm{M}\end{array}$ & $\begin{array}{l}\text { Positive outcomes: } \\
\text { vitamin E restored HaCaT cell resistance to oxidative stress induced by } \\
\text { herbicide }\end{array}$ \\
\hline $\begin{array}{l}\text { Parish et al. } \\
\text { [26], 2005 }\end{array}$ & Human keratinocytes & $\begin{array}{l}\alpha-\mathrm{TP} \\
20 \text { and } 40 \mu \mathrm{M}\end{array}$ & $\begin{array}{l}\text { Positive outcomes: } \\
\alpha \text {-TP improved barrier function measured by means of TEWL }\end{array}$ \\
\hline $\begin{array}{l}\text { De Pascale } \\
\text { et al. [27], 2006 }\end{array}$ & Human keratinocytes & $\begin{array}{l}\alpha-, \beta-, \gamma \text { - and } \delta \text {-TP } \\
50 \mu \mathrm{M}\end{array}$ & $\begin{array}{l}\text { Positive outcomes: } \\
\text { vitamin E modulated signal transduction and gene expression relevant for } \\
\text { the differentiation of keratinocytes }\end{array}$ \\
\hline $\begin{array}{l}\text { Kato et al. } \\
\text { [17], 2012 }\end{array}$ & Human keratinocytes & $\begin{array}{l}\text { Sodium DL- } \alpha \text {-tocopheryl- } \\
6-\mathrm{O} \text {-phosphate } \\
50 \mu \mathrm{M}\end{array}$ & $\begin{array}{l}\text { Positive outcomes: } \\
\text { vitamin E enhanced ceramide synthesis through the induction of } \\
\text { differentiation via an increase in intracellular Ca }{ }^{2+} \text { concentrations }\end{array}$ \\
\hline
\end{tabular}

$\alpha$-TP, $\alpha$-tocopherol; $\beta$-TP, $\beta$-tocopherol; $\gamma$-TP, $\gamma$-tocopherol; $\delta$-TP, $\delta$-tocopherol; $\mathrm{Ca}^{2+}$, calcium ion; GSH, glutathione; TEWL, transepidermal water loss; Trolox, 6-hydroxy-2,5,7,8-tetramethylchroman-2-carboxylic acid.

cellular reactive oxygen species. Glutathione levels were reported to increase at every tested $\alpha$-TP concentration, and cells cultured with $50 \mu \mathrm{M} \alpha$-TP exhibited resistance against $\mathrm{H}_{2} \mathrm{O}_{2}$. A deeper investigation on the mechanism of action of a-TP using DL-buthionine- $[\mathrm{S}, \mathrm{R}]$-sulfoximine, an inhibitor of $\gamma$-glutamyl-cysteine synthetase, showed $\alpha$-TP increases intracellular glutathione level via upregulation of the $\gamma$-glutamyl-cysteine synthetase heavy subunit mRNA [24]. In another study, Gehin et al. [25] suggested the preventive effects of vitamin $\mathrm{E}$ against deleterious cutaneous cell damage. A water-soluble analogue of vitamin E, Trolox (6-hydroxy-2,5,7,8-tetramethylchroman-2-carboxylic acid) at $100 \mu \mathrm{M}$, was shown to reduce lipid peroxidation and increase enzyme activities of superoxide dismutase, glutathione reductase and glutathione peroxidase concurrently in glyphosate-based herbicide-treated keratinocytes [25]. These findings strongly suggest the effectiveness of vitamin $\mathrm{E}$ in suppressing OS in keratinocytes.

$\mathrm{AD}$ is known to be associated with keratinocyte damage and impaired skin barrier function. Transepidermal water loss (TEWL) is the functional biomarker of skin benefit. Parish et al. [26] have shown keratinocytes treated with 20 and $40 \mu \mathrm{M}$ of $\alpha$-TP for 18 days experienced a reduction in TEWL as compared to the controls.

De Pascal et al. [27] studied the transcriptional effects of natural TP analogues $(\alpha-, \beta-, \gamma-, \delta$-TP) in normal human keratinocytes. All TP analogues at $50 \mu \mathrm{M}$ were able to induce peroxisome proliferator-activated receptor- $\gamma$ transcriptional activity via induction of its protein levels with consequent upregulation of transglutaminase-1 gene expression. Transglutaminase-1 plays a key role in terminal keratinocyte differentiation which is essential for stratum corneum (SC) formation [27]. A similar observation was also reported by Kato and Takahashi [17]. In their study, normal human epidermal keratinocytes treated with $50 \mu \mathrm{M}$ of sodium DL- $\alpha$-tocopheryl-6-Ophosphate (a hydrophilic derivative of vitamin $\mathrm{E}$ ) showed an increase in mRNA expression of differentiation markers, including transglutaminase-1, cytokeratin-10, involucrin and loricrin. Ceramide concentration in keratinocytes, a key indicator of the skin barrier function and water-retaining properties, was also increased [17].

Considering all available preclinical cellular evidence, vitamin $\mathrm{E}$ seems to hold promise as a treatment for $\mathrm{AD}$ by means of ameliorating harmful effects of OS, reducing TEWL, upregulating the gene expression of keratinocyte differentiation markers and promoting water-holding properties. A summary of the studies showing the preclinical evidence for vitamin $\mathrm{E}$ in cells is presented in Table 1.

\section{Preclinical Evidence from Animal Studies}

The role of vitamin $\mathrm{E}$ in relieving inflammation and erythema was studied by Hayashi et al. [16] using an NC/ Nga mouse model. In their study, mice were subcutane- 
ously injected in their backs with a $4 \%$ a-TP $(200 \mathrm{mg} / \mathrm{kg}$ body mass) every other day for 2 weeks. Sensitization was then carried out using 5\% picryl chloride (PC) solution followed by $0.05 \%$ PC to induce AD-like inflammation. Micetreated with PC without vitamin E treatment showed a decrease in vitamin $E$ levels and a marked increase in thiobarbituric acid reactive substance levels at the stage of peak symptom severity. Conversely, changes in thiobarbituric acid reactive substance and vitamin $E$ levels in the skin and serum were significantly inhibited in $\alpha$-TPtreated mice. Furthermore, levels of the antioxidant enzymes superoxide dismutase and glutathione peroxidase increased at peak severity in vitamin E-treated mice, as opposed to control mice. Mice treated with $\alpha$-TP were also found to have decreased levels of inflammation-associated factors such as immunoglobulin E (IgE), cyclooxygenase-2, tumour necrosis factor- $\alpha$ and nuclear factor- $\kappa B$ [16].

Tsuduki et al. [28] also employed an NC/Nga mouse model to study the influence of oral T3 on the symptoms of $\mathrm{AD}$. The mice were supplemented with $1 \mathrm{mg} /$ day of tocotrienol-rich fraction for 1 week before PC sensitization. $\mathrm{AD}$ was then induced in the mice using $1 \% \mathrm{PC}$ after sensitization with 5\% PC. The scratching behaviour, dermal thickening and serum histamine levels were greatly reduced in $\mathrm{AD}$ mice supplemented with tocotrienol-rich fraction as compared to untreated mice after 9 weeks. Further investigation into the mechanism of action showed $\mathrm{T} 3$ was able to suppress $\mathrm{AD}$ via the inhibition of protein kinase $\mathrm{C}$ activity. The antidegranulation, histamine reduction and protein kinase $\mathrm{C}$ activity suppression effects of T3 were ranked as $\delta$-T3 $>\beta$-T3 $>\gamma$-T3 $>\alpha$-T3. It is worth noting that this is the only known study to date which explored the efficacy of T3 in the direct treatment of $\mathrm{AD}$.

Kato and Takahashi [17] examined the effects of sodium DL-a-tocopheryl-6-O-phosphate on the moistureretaining properties of SC in hairless mice. The researchers discovered topical application of 1 and $2 \%$ sodium DL- $\alpha$-tocopheryl-6-O-phosphate for 4 weeks effectively improved the hygroscopicity and water-holding capacity of SC by 1.5 -fold. Next, they studied if the topical treatment would also affect the ceramide content in the SC. The obtained results reflected a 1.7 -fold increase in ceramide content after treatment, suggesting that vitamin $\mathrm{E}$ could be effective in improving skin moisture retention by enhancing ceramide synthesis.

In a recent study, dogs diagnosed with $\mathrm{AD}$ were orally treated with $\alpha$-TP (8.1 IU/kg body mass) for 8 weeks. After the course of treatment, $\alpha$-TP-treated dogs were found to have significantly higher plasma vitamin $\mathrm{E}$ and total antioxidant capacity levels as compared to the control dogs. They were also observed to have less severe lesions and obtained lower scores on the Canine Atopic Dermatitis Extent and Severity Index-03 assessment, suggesting the effectiveness of $\alpha-\mathrm{TP}$ as a treatment for $\mathrm{AD}$ in canines [29].

No adverse effects of vitamin $\mathrm{E}$ were observed in the animal studies discussed above. Collectively, vitamin E may aid in ameliorating the symptoms of $\mathrm{AD}$ by suppressing OS, inflammation and preventing further deterioration of the skin barrier function by restoring the water-retaining capacity of the SC. A summary of the studies showing the preclinical evidence for vitamin $\mathrm{E}$ in animals is presented in Table 2 .

\section{Relationship between Vitamin E and AD in Human Studies}

The following discourse is organized into 2 sections according to the relationship between vitamin $\mathrm{E}$ and $\mathrm{AD}$ in humans, that is, positive relationship (higher vitamin E intake/level, improvement in $\mathrm{AD}$ condition) and negligible relationship (no association between vitamin $\mathrm{E}$ and AD). To the best of our knowledge, there are no studies highlighting a negative relationship between vitamin $\mathrm{E}$ and skin health to date. In the following discussion, we refrain from using the term "effect" unless the study has established causality. For each section, the studies are arranged according to the type and level of evidence (casecontrol, cross-sectional or prospective studies, clinical trials).

\section{Positive Relationship between Vitamin E and Skin Health}

Several studies have reported a lower prevalence of AD in young children with higher antioxidant nutritional intakes. Based on the data of $180 \mathrm{AD}$ and 242 non-AD children between 4 and 6 years old, Oh et al. [30] observed a lower likelihood of AD in children who consumed more dietary vitamin $\mathrm{E}$, which led to higher serum $\alpha$-TP levels. A similar observation was made by Okuda et al. [31] in 396 Japanese students aged between 10 and 13 years. Questionnaires and serum antioxidant analysis revealed a significant negative association between serum $\alpha$-TP levels and the prevalence of AD. In another study, Lee et al. [32] investigated the relationship between $\alpha$-TP and serum IgE levels in Korean children aged between 0 and 24 months who were diagnosed with $\mathrm{AD}$. The findings 
Table 2. A summary showing the preclinical evidence for vitamin $\mathrm{E}$ in animal studies

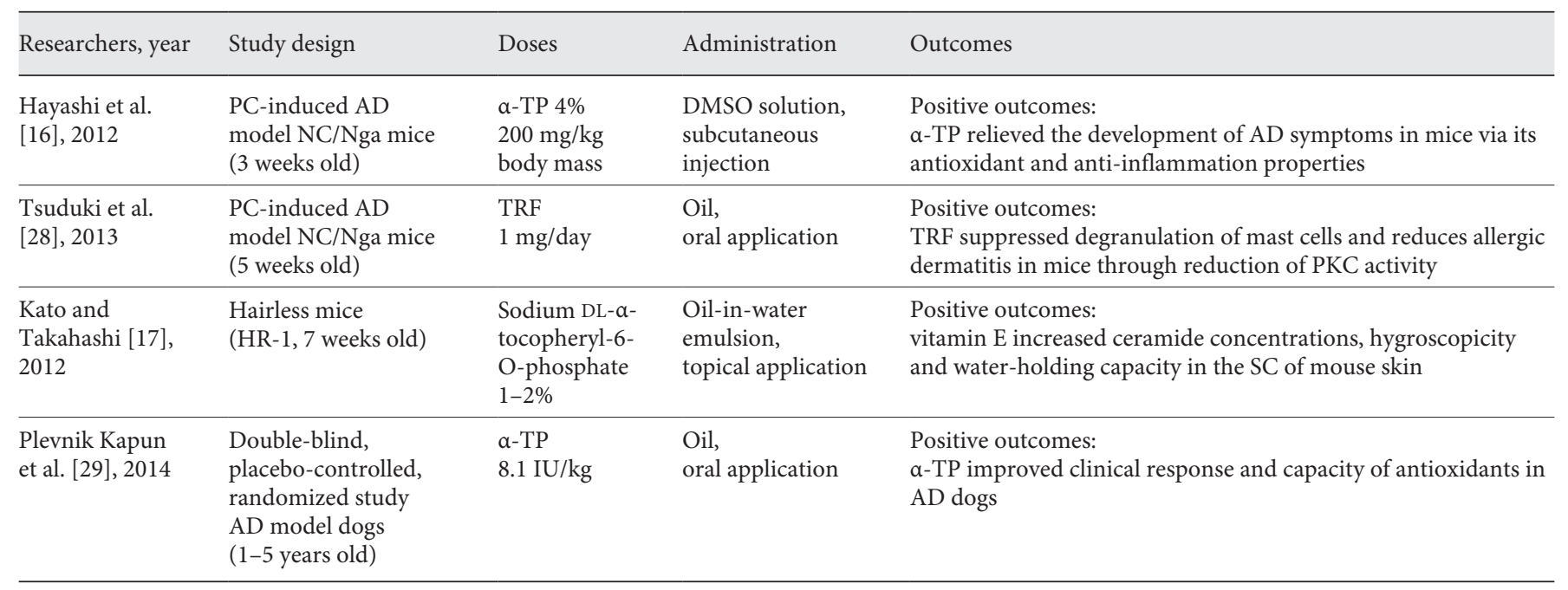

a-TP, $\alpha$-tocopherol; AD, atopic dermatitis; DMSO, dimethyl sulphoxide; PC, picryl chloride; PKC, protein kinase C; SC, stratum corneum; TRF, tocotrienol-rich fraction.

showed a strong negative association between serum $\alpha$-TP and IgE levels, suggesting the importance of maintaining a high serum $a-\mathrm{TP}$ in children diagnosed with AD. However, the study was limited to the sample size as the researchers were only able to measure serum vitamin E levels in 25 out of 119 children. This was due to the difficulty in drawing sufficient amounts of blood from children $<24$ months old.

Two prospective studies were conducted to investigate the correlation of maternal vitamin $\mathrm{E}$ levels on their infants. In 1 study, Hoppu et al. [33] recruited atopic mothers who were near the end of gestation to assess their $\alpha$ and $\gamma$-TP serum levels and the relationship with the levels in their infants. A significant correlation was detected between infants' and mothers' serum $\alpha$ - and $\gamma$-TP to fat ratios. This suggests the maternal TP status impacts that of the infant, and it is conceivable that infants whose mothers have low serum TP status may be at risk of developing atopic diseases. Martindale et al. [34] sought to examine the relationship between maternal antioxidant intake (vitamin $\mathrm{E}$, vitamin $\mathrm{C}, \beta$-carotene, selenium, magnesium, manganese, copper and zinc) in pregnancy and the prevalence of $\mathrm{AD}$ in the first 2 years of the infant's life. Their findings supplement those of Hoppu et al. [33], in which vitamin $\mathrm{E}$ intake by atopic mothers during pregnancy was found to be negatively associated with childhood AD. The authors thus postulated maternal dietary antioxidant intake during pregnancy may reduce the risk of the child developing childhood AD [34]. In all the above case-con- trol and prospective studies, interindividual differences in bioavailability and vitamin E supplementation were not considered. Several studies also made use of questionnaires or subjective assessments, which could undermine the accuracy of the results. Furthermore, while the aforementioned studies suggest a positive relationship between vitamin $\mathrm{E}$ and skin health, most did not clarify causality.

In a form of oral monotherapy, the correlation between vitamin $\mathrm{E}$ and dermatitis was reported by Olson et al. [35] in an observational study. A patient suffering from refractory hand dermatitis initiated self-medication with vitamin $\mathrm{E}$ at $400 \mathrm{mg}$ for primary prevention of coronary atherogenesis. He noted his recalcitrant hand dermatitis of 4 years started to improve unexpectedly after 9 days of treatment. Withdrawing the vitamin E supplementation led to a recurrence of palmar fissuring. The symptoms were subsequently cleared again when vitamin $\mathrm{E}$ was reinstituted. While this is only a singular case report and is unable to prove causality, it opens the door to researching the efficacy of vitamin $\mathrm{E}$ as a treatment for dermatitis in humans based on its known antioxidant and anti-inflammatory properties.

To investigate the effect of oral vitamin $\mathrm{E}$ on patients diagnosed with AD, Tsoureli-Nikita et al. [9] conducted a single-blind placebo-controlled clinical analysis to compare subjective symptoms and serum IgE levels in 96 patients after daily treatment with $400 \mathrm{IU}$ vitamin $\mathrm{E}$ for 8 months. The analysis showed that almost half of the 
subjects treated with vitamin $\mathrm{E}$ had great improvement, compared to only 1 in the placebo group. Also, 14\% of subjects in the vitamin E group showed almost complete remission of the disease, as compared to none in the placebo group. Serum IgE levels in the vitamin E group were also found to be lower than those of the placebo group [9].

The antioxidant activity of $\alpha$-T3 was demonstrated in a clinical trial by Weber et al. [10]. The researchers applied $\alpha-\mathrm{T} 3(5 \% \mathrm{w} / \mathrm{v})$ topically on the upper back of 11 subjects for 7 days and subsequently induced SC perturbation by applying $10 \%$ benzoyl peroxide to the defined area. Results suggested $\alpha-\mathrm{T} 3$ is efficacious in the prevention of lipid peroxidation but not barrier perturbation in the SC. However, this study suffers from a small sample size.

In a randomized, double-blind, placebo-controlled clinical trial conducted by Javanbakht et al. [18], 45 AD patients were divided into 4 treatment groups, each receiving either placebo, $400 \mathrm{IU}$ synthetic $\alpha$-TP or 1,600 IU vitamin $\mathrm{D}$, with various combinations. The researchers concluded $\alpha$-TP and vitamin D are equally potent in increasing erythrocyte superoxide dismutase activity in $\mathrm{AD}$ patients. They postulated a synergistic effect of $\alpha$-TP and vitamin D on erythrocyte catalase activity [18]. Using the same model, Javanbakht et al. [11] observed a similar result in another study whereby the groups receiving either a-TP or vitamin D showed reduction in the Scoring Atopic Dermatitis index by 35.7 and $34.8 \%$, respectively. Interestingly, the group that received both $\alpha$ - TP and vitamin D showed a more considerable improvement (64.3\%) compared to separate supplementation.

A clinical trial performed by Shahla et al. [19] on 100 $\mathrm{AD}$ patients across various age groups compared the subjective effects of medication with oral vitamin E. Over a period of 8 months, 50 patients received oral vitamin $\mathrm{E}$ (400 IU/day), while the other 50 patients received topical corticosteroids coupled with oral antihistamines. From the results of the posttreatment questionnaire, the authors concluded vitamin $\mathrm{E}$ may be efficacious as a treatment for $\mathrm{AD}$, with observable reductions in skin lesions and pruritus comparable to treatment with topical corticosteroid and oral antihistamines. No side effects were reported from the vitamin E treatment. However, the study was not placebo-controlled, and the dosages for topical corticosteroid and oral antihistamines were not listed. Observations and results from the clinical trial were mostly subjective and unquantified. There was no formal posttreatment clinical evaluation of the patients to validate the accuracy of observations either [19].
Jaffary et al. [12] demonstrated the relationship between oral vitamin $\mathrm{E}$ and $\mathrm{AD}$ in a double-blind, randomized, placebo-controlled trial. Sixty-five AD patients were treated with either vitamin E (400 IU/day) or placebo for 4 months in addition to the usual treatment for AD (vaseline, glycerin soap, hydroxyzine tablet and topical hydrocortisone cream 1\%). The results suggested vitamin $\mathrm{E}$ is efficacious in improving certain $\mathrm{AD}$ symptoms such as itching and lesions but not sleeplessness.

Patrizi et al. [36] conducted a double-blind, randomized, controlled trial to evaluate the efficacy of a non-steroidal topical cream (MD2011001) containing vitamin E, epigallocatechin gallate and grape seed procyanidins in treating 39 patients with mild-to-moderate AD. The measurement of the severity of $\mathrm{AD}$ was based on the Investigator's Global Assessment scale, and the results showed there was a significantly faster reduction in the $\mathrm{AD}$-affected surface area when treated with MD2011001. However, the effect of MD2011001 cannot be attributed to vitamin $\mathrm{E}$ alone as the active ingredients also included other antioxidants and emollient ingredients like epigallocatechin gallate and grape seed procyanidins. It is worth noting that adverse events were observed only in this study. Adverse events were observed in 4 patients of the placebo group (irritant contact dermatitis $=1, \mathrm{AD}$ flare $=2$, impetigo $=1$ ) and 7 patients of the MD2011001 group (irritant contact dermatitis with $\mathrm{AD}$ flare $=1$, $\mathrm{AD}$ worsening $=3$, flu-like syndrome $=1$, impetigo $=2$ ). This warrants further research on the safety and tolerability of topical vitamin E. A summary of the studies showing a positive relationship between vitamin $\mathrm{E}$ and skin health is presented in Table 3 .

\section{Negligible Relationship between Vitamin E and Skin Health}

Three prospective studies suggested a negligible relationship between vitamin E and skin health. Miyake et al. [37] studied the diet history questionnaire of 763 Japanese mother-child pairs and assessed the relationship between dietary antioxidant ( $\alpha$-carotene, $\beta$-carotene, vitamin $C$, vitamin $E$ and zinc) intake and symptoms of wheeze and $\mathrm{AD}$. Analysis of the data revealed a significant inverse relationship between maternal vitamin $\mathrm{E}$ consumption during pregnancy and wheezing, but not $\mathrm{AD}$. On the other hand, higher maternal intake of green and yellow vegetables, citrus fruits and $\beta$-carotene during pregnancy seemed to confer a reduced risk of $\mathrm{AD}$ in the infant.

This observation was also supported by Nwaru et al. [38] in their study using data from the Finnish popula- 
Table 3. A summary of the clinical studies showing a positive relationship between vitamin E and skin health

\begin{tabular}{lll}
\hline Researchers, year Study design & $\begin{array}{l}\text { Assessment, doses } \\
\text { and administration }\end{array}$ & Positive outcomes
\end{tabular}

\begin{tabular}{|c|c|c|c|}
\hline $\begin{array}{l}\text { Oh et al. } \\
{[30], 2010}\end{array}$ & $\begin{array}{l}\text { Case-control study } \\
180 \text { Korean AD and } 242 \\
\text { non-AD children }\end{array}$ & Dietary vitamin $\mathrm{E}$ & $\begin{array}{l}\text { AD was negatively associated with intake of } \\
\text { vitamin } E\end{array}$ \\
\hline
\end{tabular}

(4-6 years old)

\begin{tabular}{|c|c|c|c|}
\hline $\begin{array}{l}\text { Okuda et al. } \\
{[31], 2010}\end{array}$ & $\begin{array}{l}\text { Case-control study } \\
396 \text { Japanese students } \\
\text { (10-13 years old) }\end{array}$ & Dietary vitamin $\mathrm{E}$ & $\begin{array}{l}\text { Serum } \alpha \text {-TP, but not carotenoids, was negatively } \\
\text { associated with the prevalence of } A D\end{array}$ \\
\hline
\end{tabular}

\begin{tabular}{lll}
\hline Lee et al. & $\begin{array}{l}\text { Cross-sectional study } \\
\text { [32], 2012 }\end{array}$ & Dietary vitamin E \\
& $\begin{array}{l}\text { (19-24 morean AD children } \\
\end{array}$ & $\begin{array}{l}\text { Serum vitamin E levels were inversely associated } \\
\text { with serum total IgE and all specific IgE levels } \\
\text { A high consumption of dietary vitamin E has a } \\
\text { positive effect to ameliorate AD symptoms }\end{array}$ \\
\hline
\end{tabular}

\begin{tabular}{|c|c|c|c|}
\hline $\begin{array}{l}\text { Hoppu et al. } \\
\text { [33], } 2005\end{array}$ & $\begin{array}{l}\text { Prospective study } \\
34 \text { mothers with atopic } \\
\text { disease and their infants }\end{array}$ & $\begin{array}{l}\text { Serum level of } \\
\text { vitamin E }\end{array}$ & $\begin{array}{l}\text { Infants' serum } \alpha \text { - and } \gamma \text {-TP to fat ratios were } \\
\text { significantly correlated with maternal serum ratios } \\
\text { Maternal tocopherol status determines that of the } \\
\text { infant }\end{array}$ \\
\hline
\end{tabular}

\begin{tabular}{llll}
\hline $\begin{array}{l}\text { Martindale } \\
\text { et al. [34],2005 }\end{array}$ & $\begin{array}{l}\text { Prospective study } \\
1,924 \text { mothers and their } \\
\text { infants }\end{array}$ & Dietary vitamin E & $\begin{array}{l}\text { Maternal vitamin E intake was negatively } \\
\text { associated with the likelihood of AD during the } \\
\text { first 2 years in children with atopic mothers }\end{array}$
\end{tabular}

Olson et al. Observational study Oral softgel Patient's recalcitrant hand dermatitis of 4 years $\quad$ Causality was not proved

[35], $1994 \quad$ A 38-year-old patient $\quad 400 \mathrm{mg} / \mathrm{day} \quad$ cleared after initiation of oral vitamin E, recurred with previously refractory after the supplementation was ceased, and was palmar dermatitis cleared again with reinstitution of vitamin $\mathrm{E}$ Subsequent complete remission of signs and symptoms has been maintained with vitamin $\mathrm{E}$ supplementation

\begin{tabular}{|c|c|c|c|c|}
\hline $\begin{array}{l}\text { Tsoureli-Nikita } \\
\text { et al. [9], } 2002\end{array}$ & $\begin{array}{l}\text { Single-blind, placebo- } \\
\text { controlled, randomized } \\
\text { clinical trial } 96 \text { AD subjects } \\
\text { (10-60 years old) }\end{array}$ & $\begin{array}{l}\text { Oral softgel } \\
400 \text { IU/day } \\
\text { (8 months) }\end{array}$ & $\begin{array}{l}\text { Vitamin E supplementation improved AD clinical } \\
\text { manifestations } \\
\text { Serum vitamin E level was inversely associated } \\
\text { with serum IgE levels, with a total decrease of } 62 \% \\
\text { based on initial conditions }\end{array}$ & $\begin{array}{l}\text { Personal subjective assessment of the treatment, } \\
\text { exacerbating factors and the types of remedies may } \\
\text { lead to imprecise evaluation }\end{array}$ \\
\hline $\begin{array}{l}\text { Weber et al. } \\
{[10], 2003}\end{array}$ & $\begin{array}{l}\text { Double-blind, placebo- } \\
\text { controlled, clinical trial } \\
11 \text { subjects ( } 20-34 \text { years old })\end{array}$ & $\begin{array}{l}\text { Topical oil } \\
5 \% \mathrm{w} / \mathrm{v} \\
(7 \text { days })\end{array}$ & $\begin{array}{l}\text { a-T3 supplementation significantly mitigated the } \\
\text { BPO-induced SC barrier perturbation caused by } \\
\text { lipid peroxidation }\end{array}$ & $\begin{array}{l}\text { Small sample size may reduce the power and reliability } \\
\text { of the study }\end{array}$ \\
\hline $\begin{array}{l}\text { Javanbakht et al. } \\
{[11], 2010}\end{array}$ & $\begin{array}{l}\text { Double-blind, placebo- } \\
\text { controlled, randomized } \\
\text { clinical trial } 45 \mathrm{AD} \text { patients } \\
(13-45 \text { years old })\end{array}$ & $\begin{array}{l}\text { Oral softgel } \\
600 \mathrm{IU} / \text { day } \\
\text { (60 days) }\end{array}$ & $\begin{array}{l}\text { Vitamin } \mathrm{E} \text { and/or D supplementation alleviated } \\
\text { AD through deactivating free radicals by } \\
\text { promoting antioxidant enzymes erythrocyte SOD } \\
\text { and catalase activities in AD patients }\end{array}$ & $\begin{array}{l}\text { Small sample size may reduce the power and reliability } \\
\text { of the study }\end{array}$ \\
\hline $\begin{array}{l}\text { Javanbakht et al. } \\
{[18], 2011}\end{array}$ & $\begin{array}{l}\text { Double-blind, placebo- } \\
\text { controlled, randomized } \\
\text { clinical trial } 45 \mathrm{AD} \text { patients } \\
(13-45 \text { years old })\end{array}$ & $\begin{array}{l}\text { Oral softgel } \\
600 \mathrm{IU} / \text { day } \\
\text { (60 days) }\end{array}$ & $\begin{array}{l}\text { Vitamin } \mathrm{E} \text { and/or D supplementation improved } \\
\text { clinical manifestations of AD by reducing } \\
\text { SCORAD } \\
\text { Plasma } \alpha-\mathrm{TP} \text { was negatively associated with } \\
\text { SCORAD, intensity, objective and extent }\end{array}$ & $\begin{array}{l}\text { Small sample size and confounding factor associated } \\
\text { with the potencies of topical corticosteroid may reduce } \\
\text { the reliability of the study }\end{array}$ \\
\hline $\begin{array}{l}\text { Shahla et al. } \\
\text { [19], } 2013\end{array}$ & $\begin{array}{l}\text { Randomized clinical trial } \\
100 \mathrm{AD} \text { patients } \\
(3-40 \text { years old })\end{array}$ & $\begin{array}{l}\text { Oral softgel } \\
400 \text { IU/day } \\
\text { (8 months) }\end{array}$ & $\begin{array}{l}\text { Vitamin E may have the same effect as common } \\
\text { treatment with topical corticosteroid and oral } \\
\text { antihistamines in improving the clinical } \\
\text { manifestations of AD }\end{array}$ & $\begin{array}{l}\text { Non-placebo-controlled trial disallowed estimation of } \\
\text { the treatment sensitivity } \\
\text { Unavailability of doses for other treatment reagents } \\
\text { and utilization of personal subjective evaluation may } \\
\text { lead to imprecise results }\end{array}$ \\
\hline $\begin{array}{l}\text { Jaffary et al. } \\
{[12], 2015}\end{array}$ & $\begin{array}{l}\text { Double-blind, placebo- } \\
\text { controlled, randomized } \\
\text { clinical trial } 65 \mathrm{AD} \text { patients } \\
\text { ( } 10-50 \text { years old) }\end{array}$ & $\begin{array}{l}\text { Oral softgel } \\
400 \text { IU/day } \\
\text { (4 months) }\end{array}$ & $\begin{array}{l}\text { Itching, extent of lesions, and SCORAD index } \\
\text { improvement was significantly higher in vitamin } \\
\text { E-treated AD patients }\end{array}$ & $\begin{array}{l}\text { Unadjusted confounding variables may lead to } \\
\text { imprecise results }\end{array}$ \\
\hline $\begin{array}{l}\text { Patrizi et al. } \\
{[36], 2016}\end{array}$ & $\begin{array}{l}\text { Double-blind, placebo- } \\
\text { controlled, randomized } \\
\text { clinical trial } 39 \text { AD patients } \\
(6-69 \text { years old) }\end{array}$ & $\begin{array}{l}\text { Topical cream } \\
\text { (28 days) } \\
\text { MD2011001 } \\
\text { cream containing } \\
\text { vitamin E, EGCG } \\
\text { and grape seed } \\
\text { procyanidins }\end{array}$ & $\begin{array}{l}\text { Vitamin E-containing MD2011001 cream } \\
\text { improved the restoration and the integrity of the } \\
\text { epidermal skin barrier and cutaneous } \\
\text { inflammatory symptoms in AD patients } \\
\text { Mild to moderate side effects were reported }\end{array}$ & $\begin{array}{l}\text { Small sample size, unadjusted confounding variables } \\
\text { and unavailability of doses for vitamin E may lead to } \\
\text { imprecise results }\end{array}$ \\
\hline
\end{tabular}

$\alpha$-T3, $\alpha$-tocotrienol; $\alpha$-TP, $\alpha$-tocopherol; $\gamma$-TP, $\gamma$-tocopherol; AD, atopic dermatitis; BPO, benzoyl peroxide; EGCG, epigallocatechin gallate; IgE, immunoglobulin E; SC, stratum corneum; SCORAD, Scoring Atopic Dermatitis; SOD, superoxide dismutase.

Unavailability of supplement intake for all micronutrients, interindividual differences in bioavailability and utilization of nutrients may have underestimated the true association between some nutrients and $\mathrm{AD}$ ent intake for all micronutrients and Serum vitamin E was only measured in 25 out of the 119 children due to limited amount of blood drawn One-day 24-h recall is limited and may not represent Personal characteristics and lifestyle factors may
influence the TP status in mothers and infants

ity was not proved

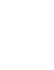


Table 4. A summary of the studies showing a negligible relationship between vitamin $\mathrm{E}$ and skin health

\begin{tabular}{lllll}
\hline Researchers, year & Study design & $\begin{array}{l}\text { Assessment, doses } \\
\text { and administration }\end{array}$ & Negligible outcomes & Notes \\
\hline $\begin{array}{l}\text { Miyake et al. } \\
{[37], 2009}\end{array}$ & $\begin{array}{l}\text { Prospective study } \\
\text { 763 Japanese mothers } \\
\text { and their children }\end{array}$ & Dietary vitamin E & $\begin{array}{l}\text { Maternal vitamin E consumption during } \\
\text { pregnancy was significantly inversely } \\
\text { related to the risk of infantile wheeze but } \\
\text { not AD }\end{array}$ & $\begin{array}{l}\text { Unadjusted confounding variables and } \\
\text { self-administered diet history } \\
\text { questionnaire may lead to imprecise } \\
\text { results }\end{array}$ \\
\hline $\begin{array}{l}\text { Nwaru et al. } \\
{[38], 2011}\end{array}$ & $\begin{array}{l}\text { Prospective study } \\
\text { 2,441 Finnish mothers } \\
\text { and their children }\end{array}$ & Dietary vitamin E & $\begin{array}{l}\text { Maternal intake of vitamin E was not } \\
\text { significantly associated with the risk of } \\
\text { asthma, rhinitis or AD in the children }\end{array}$ & $\begin{array}{l}\text { Unadjusted confounding variables and } \\
\text { self-administered diet history } \\
\text { questionnaire may lead to imprecise } \\
\text { results }\end{array}$ \\
\hline $\begin{array}{l}\text { Nwaru et al. } \\
{[39], 2013}\end{array}$ & $\begin{array}{l}\text { Prospective study } \\
1,133 \text { European mothers } \\
\text { and their children }\end{array}$ & $\begin{array}{l}\text { Serum level of } \\
\text { vitamin E }\end{array}$ & $\begin{array}{l}\text { No statistically significant associations } \\
\text { between serum vitamin E concentrations } \\
\text { at year 1 and AD }\end{array}$ & $\begin{array}{l}\text { Unadjusted confounding variables and } \\
\text { self-administered questionnaire may lead } \\
\text { to imprecise results }\end{array}$ \\
\hline
\end{tabular}

$\mathrm{AD}$, atopic dermatitis.

tion-based birth cohort nutritional study with a 5-year follow-up. The researchers proposed no significant association between maternal intake of antioxidants ( $\alpha$-carotene, $\beta$-carotene, vitamin $\mathrm{C}, \alpha$-TP, $\gamma$-TP, zinc, copper, selenium, magnesium, calcium, manganese, folate, riboflavin and retinol) and the risk of atopic diseases such as AD, except for the dietary intake of magnesium, which had an independent association with protection against $\mathrm{AD}$ in children.

Another study by Nwaru et al. [39] sought to investigate the association between serum vitamin $\mathrm{E}(\alpha-$ and $\gamma$-TP) concentrations and the development of atopic diseases up to 6 years in life. Measurements of serum vitamin E levels and periodic observation for symptoms of various atopic diseases such as wheezing, asthma and AD starting from year 1 were performed in 1,133 mother-child pairs. No statistically significant associations between $\alpha$ - or $\gamma$-TP serum concentrations and atopic sensitization or $\mathrm{AD}$ were observed. However, serum vitamin $\mathrm{E}$ was only measured at one time point at year 1. Repeated measurements of serum vitamin $E$ levels over the years might have provided a more accurate analysis of the relationship between serum vitamin E levels and AD. A summary of the studies showing a negligible relationship between vitamin $\mathrm{E}$ and skin health is presented in Table 4.

\section{Perspective}

The term vitamin $\mathrm{E}$ has been used indiscriminately in many studies, commonly referring to $\alpha-T P$. This could be attributed to the disproportionately large number of studies performed on $\alpha-\mathrm{TP}$ as it is the most abundant form of vitamin $\mathrm{E}$ found in nature and the human body. Researchers should be more specific in the description of the forms of vitamin $\mathrm{E}$ employed in their studies. While most of the current studies have suggested the effectiveness of $\alpha$-TP and its derivative forms in AD, not many have explored the efficacy of T3. T3 possesses powerful neuroprotective, cholesterol-lowering, anti-aging, antiinflammatory and anticancer properties that are often not fully exhibited by TP [40-44]. It is thus worth further investigating the specific mechanism of action of different T3 isoforms in treating $\mathrm{AD}$.

Administration of vitamin $\mathrm{E}$ in clinical studies is predominantly oral and transdermal. Although it has been postulated to be more potent in its antioxidative and antiinflammatory abilities, T3 may suffer from the hindrance of poor pharmacokinetic profile and low bioavailability as compared to $\alpha$-TP. This is mainly due to the lack of affinity to $\alpha$-TP transport protein and catabolization by $\omega$-hydroxylase in the body $[45,46]$. Nanotechnology interventions, for example, the nanoparticles, nanoemulsions and liposomes, could be further researched to enhance the encapsulation, stability and permeation of natural vitamin $\mathrm{E}$.

On the other hand, the topical use of vitamin $\mathrm{E}$ has raised concern about allergic contact dermatitis (ACD) in $\mathrm{AD}$ patients. Contact allergy to vitamin $\mathrm{E}$ and its derivatives, mainly the synthetic form, has been described in a few individual case reports. A study conducted in 1991 detailed 4 cases of ACD caused by tocopheryl acetate $10 \%$ petrolatum-containing cream. Erythema, urticarial papules and papulovesicular dermatitis on different parts of the body are among the clinical observations using patch tests. All patients reported no recurrence of allergic symp- 


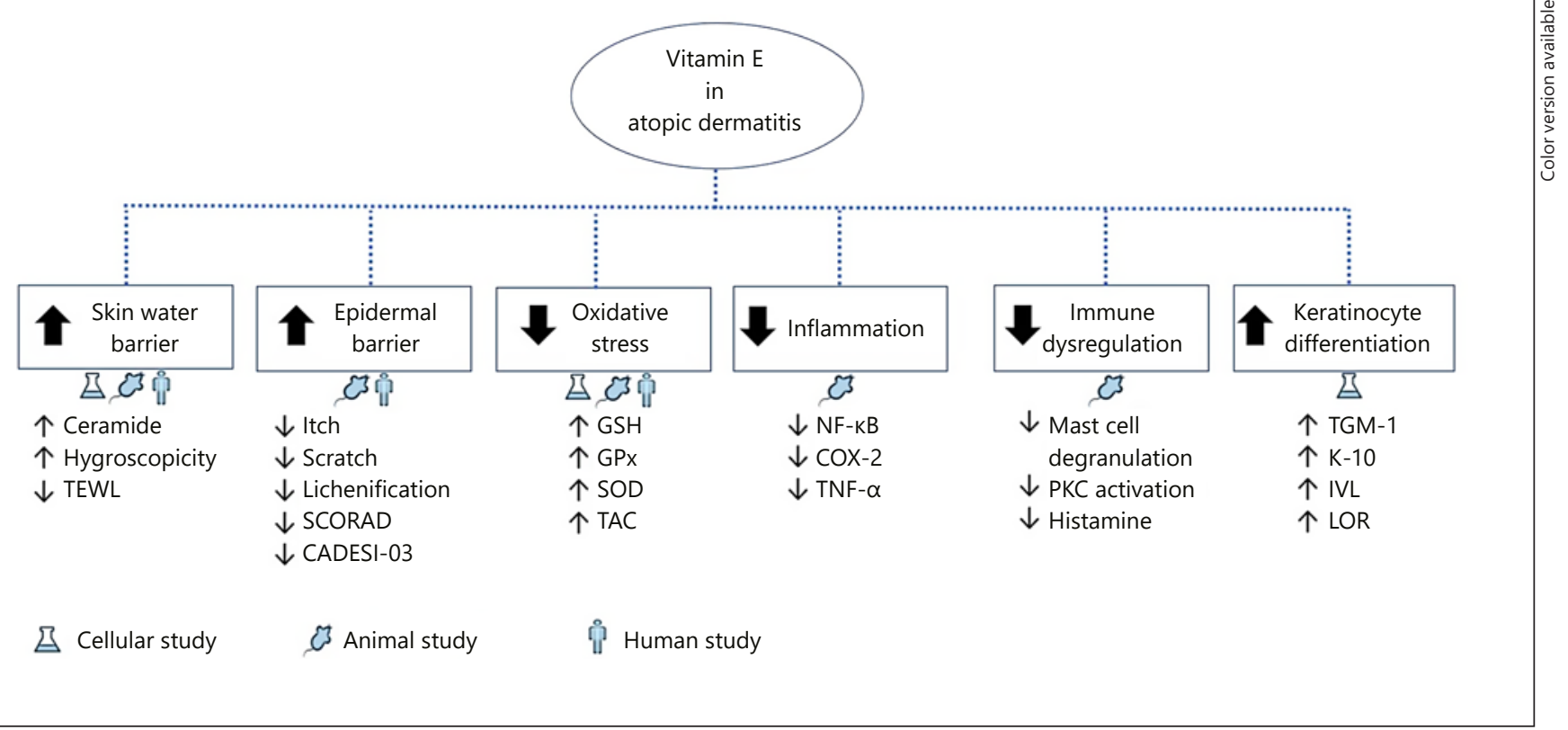

Fig. 2. Summary of vitamin E efficacy in atopic dermatitis. TEWL, transepidermal water loss; SCORAD, Scoring Atopic Dermatitis index; CADESI-03, Canine Atopic Dermatitis Extent and Severity Index-03; GSH, glutathione; GPx, glutathione peroxidase; SOD, superoxide dismutase; TAC, total antioxidant capacity; NF- $\kappa \mathrm{B}$, nuclear factor- $\kappa \mathrm{B}$; COX-2, cyclo-oxygenase-2; TNF- $\alpha$, tumour necrosis factor- $\alpha$; PKC, protein kinase C; TGM-1, transglutaminase-1; K-10, cytokeratin-10; IVL, involucrin; LOR, loricrin. toms after discontinuing the cream [47]. In another case, patch testing in a patient with erythema multiforme-like eruption indicated a positive allergic reaction to tocopheryl acetate 5\% petrolatum [48]. Apart from the topical application, dietary vitamin $\mathrm{E}$ was also reported as the cause of ACD. In a recent case, a patient with long-standing $\mathrm{AD}$ that fails to improve with topical therapy, which include ammonium lactate, hypoallergenic emollients, hydrocortisone cream, fluocinolone ointment and steroids, experienced a dramatic improvement of his widespread AD after avoiding TP from diet and topical products. His AD recurred following reintroduction of dietary products high in TP, and resolution of the dermatitis was again achieved through allergen avoidance [49]. Although vitamin E has been described as the cause of ACD in some sporadic cases, the incident rate is fairly low despite its widespread use [47, 50, 51].

The skin and gut microbiomes are intimately linked via the "skin-gut axis" and exhibit several comorbidities $[52,53]$. AD patients were reported to have a shift in their skin and gut microbial diversity, where that of the bacterial commensals is lower and that of the pathogens higher than in healthy individuals $[54,55]$. The density of pathogenic Staphylococcus genera especially S. aureus is higher while Cutibacterium, Streptococcus, Acinetobacter, Corynebacterium and Prevotella are declined during an AD flare $[55,56]$. S. aureus is a superantigen that aggravates $A D$ by producing several virulent agents such as a-toxin that impairs the skin barrier or protein A that triggers an inflammatory response from keratinocytes and proteases that dissolves the SC [57-60]. Disequilibrium of the gut microbiome could impact the development of $\mathrm{AD}$ through immunological, metabolic and neuroendocrine pathways [61-65]. Bacterial colonization in the gut during infancy shaped the development of the immune system later in life $[66,67]$. Infants with low Bifidobacterium, Bacteroides, Akkermansia and Faecalibacterium density in the gut have been associated with subsequent $\mathrm{AD}$. In addition, it was found that the abundances of S. aureus, Clostridium difficile and Escherichia coli are higher in AD infants compared to healthy controls [6871]. Rebalancing the microbiome will be essential to maintain a healthy community in the skin and gut. Exploring the possibility and synergistic effect of vitamin $\mathrm{E}$ and probiotics either as an oral supplementation (from inside to the outer skin layers) or transdermal application (from outside to inside the skin) would be a good approach in $\mathrm{AD}$ management. 


\section{Conclusion}

The progression of $\mathrm{AD}$ has been attributed to OS, inflammation and degenerating skin barrier function. This is evidenced by increased oxidative damage, inflammation-associated markers, serum IgE levels, TEWL and reduced antioxidant levels. The existing studies largely suggest a positive relationship between vitamin $\mathrm{E}$ and skin health as illustrated in Figure 2. As such, vitamin E holds promise as an adjunctive treatment for $\mathrm{AD}$ and other skin disorders stemming from OS and inflammation. Topical application of $5 \%$ and a daily dosage up to $600 \mathrm{IU}$ of vitamin E can be considered safe in humans. Albeit rare, the risk of contact allergy to topical vitamin $E$ should not be disregarded. The different isoforms of vitamin $\mathrm{E}$ and their delivery system should also be explored to validate their efficacy in the treatment of $\mathrm{AD}$ and other skin disorders.

\section{Key Message}

Vitamin E could be an effective adjunctive treatment for atopic dermatitis patients.

\section{Conflict of Interest Statement}

C.W.L.T. and W.N.Y. work for Davos Life Science (a subsidiary of KLK Oleo). Y.W.U. works for KLK Oleo, a manufacturer of tocotrienols. The rest of the authors have no conflicts of interest to declare.

\section{Funding Sources}

This work was financially supported by a research grant from KL-Kepong Oleomas Sdn Bhd (KLK Oleo) to Davos Life Science Pte Ltd.

\section{Author Contributions}

C.W.L.T. and S.H.Y.T. were responsible for acquisition and interpretation of data and drafting the manuscript for this work. H.L.T., Y.W.U. and W.N.Y. critically revised the work for important intellectual content and flow of ideas. All authors provided final approval of the version to be published and agree to be accountable for all aspects of the work.

\section{References}

1 Nutten S. Atopic dermatitis: global epidemiology and risk factors. Ann Nutr Metab. 2015; 66(Suppl 1):8-16.

2 Boguniewicz M, Leung DY. Atopic dermatitis: a disease of altered skin barrier and immune dysregulation. Immunol Rev. $2011 \mathrm{Jul}$; 242(1):233-46.

3 McPherson T. Current Understanding in Pathogenesis of Atopic Dermatitis. Indian J Dermatol. 2016 Nov-Dec;61(6):649-55.

4 David Boothe W, Tarbox JA, Tarbox MB. Atopic Dermatitis: pathophysiology. Adv Exp Med Biol. 2017;1027:21-37.

5 Ji H, Li XK. Oxidative Stress in Atopic Dermatitis. Oxid Med Cell Longev. 2016;2016: 2721469.

6 Wullaert A, Bonnet MC, Pasparakis M. NF$\kappa \mathrm{B}$ in the regulation of epithelial homeostasis and inflammation. Cell Res. 2011 Jan;21(1): 146-58.

7 Kruk J, Duchnik E. Oxidative stress and skin diseases: possible role of physical activity. Asian Pac J Cancer Prev. 2014;15(2):561-8.

8 Alexander T, Maxim E, Cardwell LA, Chawla A, Feldman SR. Prescriptions for atopic dermatitis: oral corticosteroids remain commonplace. J Dermatolog Treat. 2018 May;29(3): 238-40.

9 Tsoureli-Nikita E, Hercogova J, Lotti T, Menchini G. Evaluation of dietary intake of vitamin $\mathrm{E}$ in the treatment of atopic dermati- tis: a study of the clinical course and evaluation of the immunoglobulin E serum levels. Int J Dermatol. 2002 Mar;41(3):146-50.

10 Weber SU, Thiele JJ, Han N, Luu C, Valacchi G, Weber S, et al. Topical alpha-tocotrienol supplementation inhibits lipid peroxidation but fails to mitigate increased transepidermal water loss after benzoyl peroxide treatment of human skin. Free Radic Biol Med. 2003 Jan; 34(2): 170-6.

11 Javanbakht MH, Keshavarz SA, Djalali M, Siassi F, Eshraghian MR, Firooz A, et al. Randomized controlled trial using vitamins $\mathrm{E}$ and D supplementation in atopic dermatitis. J Dermatolog Treat. 2011 Jun;22(3):144-50.

12 Jaffary F, Faghihi G, Mokhtarian A, Hosseini SM. Effects of oral vitamin $\mathrm{E}$ on treatment of atopic dermatitis: A randomized controlled trial. J Res Med Sci. 2015 Nov;20(11):1053-7.

13 Serbinova E, Kagan V, Han D, Packer L. Free radical recycling and intramembrane mobility in the antioxidant properties of alpha-tocopherol and alpha-tocotrienol. Free Radic Biol Med. 1991;10(5):263-75.

14 Suzuki YJ, Tsuchiya M, Wassall SR, Choo YM, Govil G, Kagan VE, et al. Structural and dynamic membrane properties of alpha-tocopherol and alpha-tocotrienol: implication to the molecular mechanism of their antioxidant potency. Biochemistry. 1993 Oct;32(40): 10692-9.
15 Packer L, Weber SU, Rimbach G. Molecular aspects of alpha-tocotrienol antioxidant action and cell signalling. J Nutr. 2001 Feb; 131(2):369S-73S.

16 Hayashi D, Sugaya H, Ohkoshi T, Sekizawa K, Takatsu H, Shinkai T, et al. Vitamin E improves biochemical indices associated with symptoms of atopic dermatitis-like inflammation in NC/Nga mice. J Nutr Sci Vitaminol (Tokyo). 2012;58(3):161-8.

17 Kato E, Takahashi N. Improvement by sodium dl- $\alpha$-tocopheryl-6-O-phosphate treatment of moisture-retaining ability in stratum corneum through increased ceramide levels. Bioorg Med Chem. 2012 Jun;20(12):3837-42.

18 Javanbakht M, Keshavarz S, Mirshafiey A, Djalali M, Siassi F, Eshraghian M, et al. The effects of vitamins e and d supplementation on erythrocyte superoxide dismutase and catalase in atopic dermatitis. Iran J Public Health. 2010;39(1):57-63.

19 Shahla B, Mehdi A, Effat K, Pegah NA, Hossein A, Sahar M, et al. Effect of Oral Vitamin E on Atopic Dermatitis. J Clin Res Gov. 2013; 2(2).

20 Damiani G, Eggenhöffner R, Pigatto PD, Bragazzi NL. Nanotechnology meets atopic dermatitis: current solutions, challenges and future prospects. Insights and implications from a systematic review of the literature. Bioact Mater. 2019 Dec;4:380-6. 
21 Maniam G, Mai CW, Zulkefeli M, Dufès C, Tan DM, Fu JY. Challenges and opportunities of nanotechnology as delivery platform for tocotrienols in cancer therapy. Front Pharmacol. 2018 Nov;9:1358.

22 Tamura T, Otulakowski G, Kavanagh BP. Could nanotechnology make vitamin E therapeutically effective? Am J Physiol Lung Cell Mol Physiol. 2019 Jan;316(1):L1-5.

$23 \mathrm{Yu}$ J, Chen Z, Yin YZ, Tang C, Hu E, Zheng S, et al. Improving Topical Skin Delivery of Monocrotaline Via Liposome Gel-based Nanosystems. Curr Drug Deliv. 2019;16(10): 940-50.

24 Masaki H, Okano Y, Ochiai Y, Obayashi K, Akamatsu H, Sakurai H. alpha-tocopherol increases the intracellular glutathione level in HaCaT keratinocytes. Free Radic Res. 2002 Jun;36(6):705-9.

25 Gehin A, Guyon C, Nicod L. Glyphosate-induced antioxidant imbalance in HaCaT: The protective effect of Vitamins $\mathrm{C}$ and $\mathrm{E}$. Environ Toxicol Pharmacol. 2006 Jul;22(1):27-34.

26 Parish WE, Read J, Paterson SE. Changes in basal cell mitosis and transepidermal water loss in skin cultures treated with vitamins $\mathrm{C}$ and E. Exp Dermatol. 2005 Sep;14(9):684-91.

27 De Pascale MC, Bassi AM, Patrone V, Villacorta L, Azzi A, Zingg JM. Increased expression of transglutaminase- 1 and PPARgamma after vitamin E treatment in human keratinocytes. Arch Biochem Biophys. 2006 Mar; 447(2):97-106

28 Tsuduki T, Kuriyama K, Nakagawa K, Miyazawa T. Tocotrienol (unsaturated vitamin E) suppresses degranulation of mast cells and reduces allergic dermatitis in mice. J Oleo Sci. 2013;62(10):825-34.

29 Plevnik Kapun A, Salobir J, Levart A, Tavčar Kalcher G, Nemec Svete A, Kotnik T. Vitamin E supplementation in canine atopic dermatitis: improvement of clinical signs and effects on oxidative stress markers. Vet Rec. 2014 Dec;175(22):560.

30 Oh SY, Chung J, Kim MK, Kwon SO, Cho BH. Antioxidant nutrient intakes and corresponding biomarkers associated with the risk of atopic dermatitis in young children. Eur J Clin Nutr. 2010 Mar;64(3):245-52.

31 Okuda M, Bando N, Terao J, Sasaki S, Sugiyama S, Kunitsugu I, et al. Association of serum carotenoids and tocopherols with atopic diseases in Japanese children and adolescents. Pediatr Allergy Immunol. 2010 Jun;21(4 Pt 2):e705-10

32 Lee S, Ahn K, Paik HY, Chung SJ. Serum immunoglobulin E (IgE) levels and dietary intake of Korean infants and young children with atopic dermatitis. Nutr Res Pract. 2012 Oct;6(5):429-35.

33 Hoppu U, Salo-Väänänen P, Lampi AM, Isolauri E. Serum alpha- and gamma-tocopherol levels in atopic mothers and their infants are correlated. Biol Neonate. 2005;88(1):24-6.
34 Martindale S, McNeill G, Devereux G, Campbell D, Russell G, Seaton A. Antioxidant intake in pregnancy in relation to wheeze and eczema in the first two years of life. Am J Respir Crit Care Med. 2005 Jan;171(2):121-8.

35 Olson PE, Torp EC, Mahon RT, Weiss PJ, Wallace MR. Oral vitamin E for refractory hand dermatitis. Lancet. 1994 Mar;343(8898): 672-3.

36 Patrizi A, Raone B, Neri I, Gurioli C, Carbonara M, Cassano N, et al. Randomized, controlled, double-blind clinical study evaluating the safety and efficacy of MD2011001 cream in mild-to-moderate atopic dermatitis of the face and neck in children, adolescents and adults. J Dermatolog Treat. 2016 Aug;27(4): $346-50$.

37 Miyake Y, Sasaki S, Tanaka K, Hirota Y. Consumption of vegetables, fruit, and antioxidants during pregnancy and wheeze and eczema in infants. Allergy. 2010 Jun;65(6):75865.

38 Nwaru BI, Erkkola M, Ahonen S, Kaila M, Kronberg-Kippilä C, Ilonen J, et al. Intake of antioxidants during pregnancy and the risk of allergies and asthma in the offspring. Eur J Clin Nutr. 2011 Aug;65(8):937-43.

39 Nwaru BI, Virtanen SM, Alfthan G, Karvonen AM, Genuneit J, Lauener RP, et al.; PASTURE study group. Serum vitamin E concentrations at 1 year and risk of atopy, atopic dermatitis, wheezing, and asthma in childhood: the PASTURE study. Allergy. 2014 Jan;69(1):87-94.

40 Sen CK, Khanna S, Roy S, Packer L. Molecular basis of vitamin $\mathrm{E}$ action. Tocotrienol potently inhibits glutamate-induced pp60(c-Src) kinase activation and death of HT4 neuronal cells. J Biol Chem. 2000 Apr;275(17):1304955.

41 Qureshi AA, Qureshi N, Hasler-Rapacz JO, Weber FE, Chaudhary V, Crenshaw TD, et al. Dietary tocotrienols reduce concentrations of plasma cholesterol, apolipoprotein B, thromboxane $\mathrm{B} 2$, and platelet factor 4 in pigs with inherited hyperlipidemias. Am J Clin Nutr. 1991 Apr;53(4 Suppl):1042S-6S

42 Adachi H, Ishii N. Effects of tocotrienols on life span and protein carbonylation in Caenorhabditis elegans. J Gerontol A Biol Sci Med Sci. 2000 Jun;55(6):B280-5.

43 Noguchi N, Hanyu R, Nonaka A, Okimoto Y, Kodama T. Inhibition of THP-1 cell adhesion to endothelial cells by $\alpha$-tocopherol and a-tocotrienol is dependent on intracellular concentration of the antioxidants. Free Radic Biol Med. 2003 Jun;34(12):1614-20.

44 Chang PN, Yap WN, Lee DT, Ling MT, Wong YC, Yap YL. Evidence of gamma-tocotrienol as an apoptosis-inducing, invasion-suppressing, and chemotherapy drug-sensitizing agent in human melanoma cells. Nutr Cancer. 2009;61(3):357-66.

45 Hosomi A, Arita M, Sato Y, Kiyose C, Ueda T, Igarashi $\mathrm{O}$, et al. Affinity for alpha-tocopherol transfer protein as a determinant of the biological activities of vitamin $\mathrm{E}$ analogs. FEBS Lett. 1997 Jun;409(1):105-8.
46 Sontag TJ, Parker RS. Cytochrome P450 omega-hydroxylase pathway of tocopherol catabolism. Novel mechanism of regulation of vitamin E status. J Biol Chem. 2002 Jul;277(28): 25290-6.

47 de Groot AC, Berretty PJ, van Ginkel CJ, den Hengst CW, van Ulsen J, Weyland JW. Allergic contact dermatitis from tocopheryl acetate in cosmetic creams. Contact Dermat. 1991 Nov;25(5):302-4.

48 Ohko K, Ito A, Ito M. Allergic Contact Dermatitis Syndrome Due to Tocopherol Acetate, in Addition to Glycyrrhetinic Acid. J Cosmet Dermatological Sci Appl. 2012 Mar; 2(1):38-40

49 Chen R, Raffi J, Murase JE. Tocopherol Allergic Dermatitis Masquerading as Lifelong Atopic Dermatitis. Dermatitis. 2020 Jan; 31(1):e3-4.

50 Adams AK, Connolly SM. Allergic contact dermatitis from vitamin E: the experience at Mayo Clinic Arizona, 1987 to 2007. Dermatitis. 2010 Jul-Aug;21(4):199-202.

51 Kosari P, Alikhan A, Sockolov M, Feldman SR. Vitamin E and allergic contact dermatitis. Dermatitis. 2010 May-Jun;21(3):148-53.

52 Arck P, Handjiski B, Hagen E, Pincus M, Bruenahl $\mathrm{C}$, Bienenstock $\mathrm{J}$, et al. Is there a 'gut-brain-skin axis'? Exp Dermatol. 2010 May;19(5):401-5.

53 Vaughn AR, Notay M, Clark AK, Sivamani RK. Skin-gut axis: the relationship between intestinal bacteria and skin health. World J Dermatology. 2017 Nov;6(4):52-8.

54 Kim JE, Kim HS. Microbiome of the Skin and Gut in Atopic Dermatitis (AD): Understanding the Pathophysiology and Finding Novel Management Strategies. J Clin Med. 2019 Apr;8(4):444.

55 Kong HH, Oh J, Deming C, Conlan S, Grice EA, Beatson MA, et al.; NISC Comparative Sequence Program. Temporal shifts in the skin microbiome associated with disease flares and treatment in children with atopic dermatitis. Genome Res. 2012 May;22(5): 850-9.

56 Oh J, Freeman AF, Park M, Sokolic R, Candotti F, Holland SM, et al.; NISC Comparative Sequencing Program. The altered landscape of the human skin microbiome in patients with primary immunodeficiencies. Genome Res. 2013 Dec;23(12):2103-14.

57 Berube BJ, Bubeck Wardenburg J. Staphylococcus aureus a-toxin: nearly a century of intrigue. Toxins (Basel). 2013 Jun;5(6):114066.

58 Geoghegan JA, Irvine AD, Foster TJ. Staphylococcus aureus and Atopic Dermatitis: A Complex and Evolving Relationship. Trends Microbiol. 2018 Jun;26(6):484-97.

59 Nakatsuji T, Chen TH, Two AM, Chun KA, Narala S, Geha RS, et al. Staphylococcus aureus Exploits Epidermal Barrier Defects in Atopic Dermatitis to Trigger Cytokine Expression. J Invest Dermatol. 2016 Nov; 136(11):2192-200. 
60 Spaulding AR, Salgado-Pabón W, Kohler PL, Horswill AR, Leung DY, Schlievert PM. Staphylococcal and streptococcal superantigen exotoxins. Clin Microbiol Rev. 2013 Jul; 26(3):422-47.

61 Cryan JF, Dinan TG. Mind-altering microorganisms: the impact of the gut microbiota on brain and behaviour. Nat Rev Neurosci. 2012 Oct;13(10):701-12.

62 Fujimura KE, Sitarik AR, Havstad S, Lin DL, Levan S, Fadrosh D, et al. Neonatal gut microbiota associates with childhood multisensitized atopy and $\mathrm{T}$ cell differentiation. Nat Med. 2016 Oct;22(10):1187-91.

63 Jin UH, Lee SO, Sridharan G, Lee K, Davidson LA, Jayaraman A, et al. Microbiome-derived tryptophan metabolites and their aryl hydrocarbon receptor-dependent agonist and antagonist activities. Mol Pharmacol. 2014 May; 85(5):777-88.
64 Kaikiri H, Miyamoto J, Kawakami T, Park SB, Kitamura N, Kishino S, et al. Supplemental feeding of a gut microbial metabolite of linoleic acid, 10-hydroxy-cis-12-octadecenoic acid, alleviates spontaneous atopic dermatitis and modulates intestinal microbiota in $\mathrm{NC} /$ nga mice. Int J Food Sci Nutr. 2017 Dec;68(8): 941-51.

65 Lee SY, Lee E, Park YM, Hong SJ. Microbiome in the gut-skin axis in atopic dermatitis. Allergy Asthma Immunol Res. 2018 Jul;10(4): 354-62.

66 Belkaid Y, Segre JA. Dialogue between skin microbiota and immunity. Science. 2014 Nov; 346(6212):954-9.

67 Geuking MB, Cahenzli J, Lawson MA, Ng DC, Slack E, Hapfelmeier S, et al. Intestinal bacterial colonization induces mutualistic regulatory $\mathrm{T}$ cell responses. Immunity. $2011 \mathrm{May}$ 34(5):794-806.
68 Abrahamsson TR, Jakobsson HE, Andersson AF, Björkstén B, Engstrand L, Jenmalm MC. Low diversity of the gut microbiota in infants with atopic eczema. J Allergy Clin Immunol. 2012 Feb;129(2):434-40.

69 Kalliomäki M, Kirjavainen P, Eerola E, Kero P, Salminen S, Isolauri E. Distinct patterns of neonatal gut microflora in infants in whom atopy was and was not developing. J Allergy Clin Immunol. 2001 Jan;107(1):129-34.

70 Kirjavainen PV, Arvola T, Salminen SJ, Isolauri E. Aberrant composition of gut microbiota of allergic infants: a target of bifidobacterial therapy at weaning? Gut. 2002 Jul;51(1): 51-5.

71 Nylund L, Nermes M, Isolauri E, Salminen S, de Vos WM, Satokari R. Severity of atopic disease inversely correlates with intestinal microbiota diversity and butyrate-producing bacteria. Allergy. 2015 Feb;70(2):241-4. 